\title{
ADDITIONAL OBSERVATIONS OF PUTATIVE HOST SPECIES FEEDING ONLY COWBIRD FLEDGLINGS
}

Spencer G. Sealy

Department of Biological Sciences

University of Manitoba

Winnipeg, MB R3T 2N2

Spencer.Sealy@umanitoba.ca

The time when a young bird leaves (fledges) from the nest until it becomes independent, i.e., the fledgling period, ${ }^{1,2}$ is an under-studied phase of the annual cycle of birds, particularly of hosts of brood-parasitic cowbirds (Molothrus spp.). Smith ${ }^{3}$ reported that fledgling Song Sparrows (Melospiza melodia), colour marked to facilitate individual recognition, experienced no significant reduction in survival due to cowbird parasitism, whereas evidence from other studies suggests otherwise. In a study of reproductive success of Indigo Buntings (Passerina cyanea), reduced survival of fledglings was found in which juvenile buntings fledged from parasitized nests were 82 per cent less likely to return to natal areas in their second year than juvenile buntings from unparasitized nests. ${ }^{4}$ This result has been augmented by numerous anecdotal field observations ${ }^{5-8}$, and results of a radio-telemetry study ${ }^{9}$ of hosts that tended cowbird fledglings but none of their own. The high frequency of observations of hosts feeding only fledged cowbirds points strongly towards the host's fledglings having died prior to or soon after leaving the nest rather than being fed elsewhere, possibly by the other host parent. 7,8 These observations are usually assumed to involve the species that reared the cowbird, being mindful that individuals of other species occasionally join in the feeding. ${ }^{10,11}$

I document five observations of putative hosts feeding only fledged Brown-headed Cowbirds (M. ater). The observations were made between 1986 and 1993, one in southwestern Saskatchewan (near Val Marie), one involving two "host" species from southwestern Manitoba (Turtle Mountain Provincial Park), and three during studies of cowbird host use in the dune-ridge forest that separates Lake Manitoba and Delta Marsh, Manitoba. ${ }^{12}$

These observations augment a compilation of more than 225 previous observations of family groups consisting of parasitized species feeding only cowbird fledglings (Table 1), but accurate documentation of survival of host and cowbird fledglings will require tracking radio-marked, known-age fledglings over the entire fledgling period.

\section{Stages of Cowbird Development}

For the observations presented here, I assigned each fledgling Brown-headed Cowbird to one of four main stages of development between leaving the nest and independence, as proposed by Woodward $^{13}$ : inactive, active, super- active, and independent. The inactive stage is an extension of the late nestling period, and lasts for up to three days; fledglings occasionally utter chipping sounds and generally perch quietly except when being fed. The active stage lasts most of the fledgling period, from three to 13 days out of the nest; characterized by hourly bouts of flight, pecking, pecking and walking, and dropping to the ground. The super-active stage is from 12 to 23 days of age out of the nest and three to 11 days to independence; young constantly flying after hosts, actively begging with quivering wings and loud calling. Brown-headed Cowbird fledglings gain independence 16 to 28 days after leaving the nest, when adults have stopped feeding them.

\section{Observations}

Common Yellowthroat/Chestnutsided Warbler (Active stage of Woodward ${ }^{13}$; cowbird three to 13 days out of nest) - For almost 40 minutes, I watched a Brownheaded Cowbird fledgling initially begging loudly and being fed alternately by a male Common Yellowthroat (Geothlypis trichas)

\begin{tabular}{|l|l|l|}
\hline \multicolumn{1}{|c|}{ LOCALITY } & $\begin{array}{c}\text { NUMBER OF RECORDS OF ADULTS } \\
\text { FEEDING ONLY BROWN-HEADED } \\
\text { COWBIRD FLEDGLING(S) }(\%)\end{array}$ & \multicolumn{1}{|c|}{ SOURCE } \\
\hline Sierra Nevada, CA & 18 of $25(72 \%)^{\mathrm{a}}$ & Airola $^{5}$ \\
\hline Illinois & 107 of $127(84 \%)$ & Robinson $^{6}$ \\
\hline North America/Mexico & Rasmussen and Sealy ${ }^{8}$ \\
\hline
\end{tabular}

TABLE 1: Number of records of host species recorded only feeding Brown-headed Cowbird fledglings. Note: data are from three separate studies; each record consists of an observation of one or two adult birds, the putative parents, feeding only a cowbird fledgling(s).

a. Interpreted another way: of 25 different family groups of fledglings, involving eight putative host species accurately determined to include Brown-headed Cowbird young, 18 (72 per cent) contained no host young, whereas seven groups consisted of adults feeding not only a cowbird fledgling but also at least one of their own young. In addition, of eight groups with $>1$ cowbird young, none contained host young. ${ }^{5}$

b. Records of family groups involving 45 host species extracted from the literature from throughout the Brown-headed Cowbird's range, excluding the data summarized in the two rows above. 


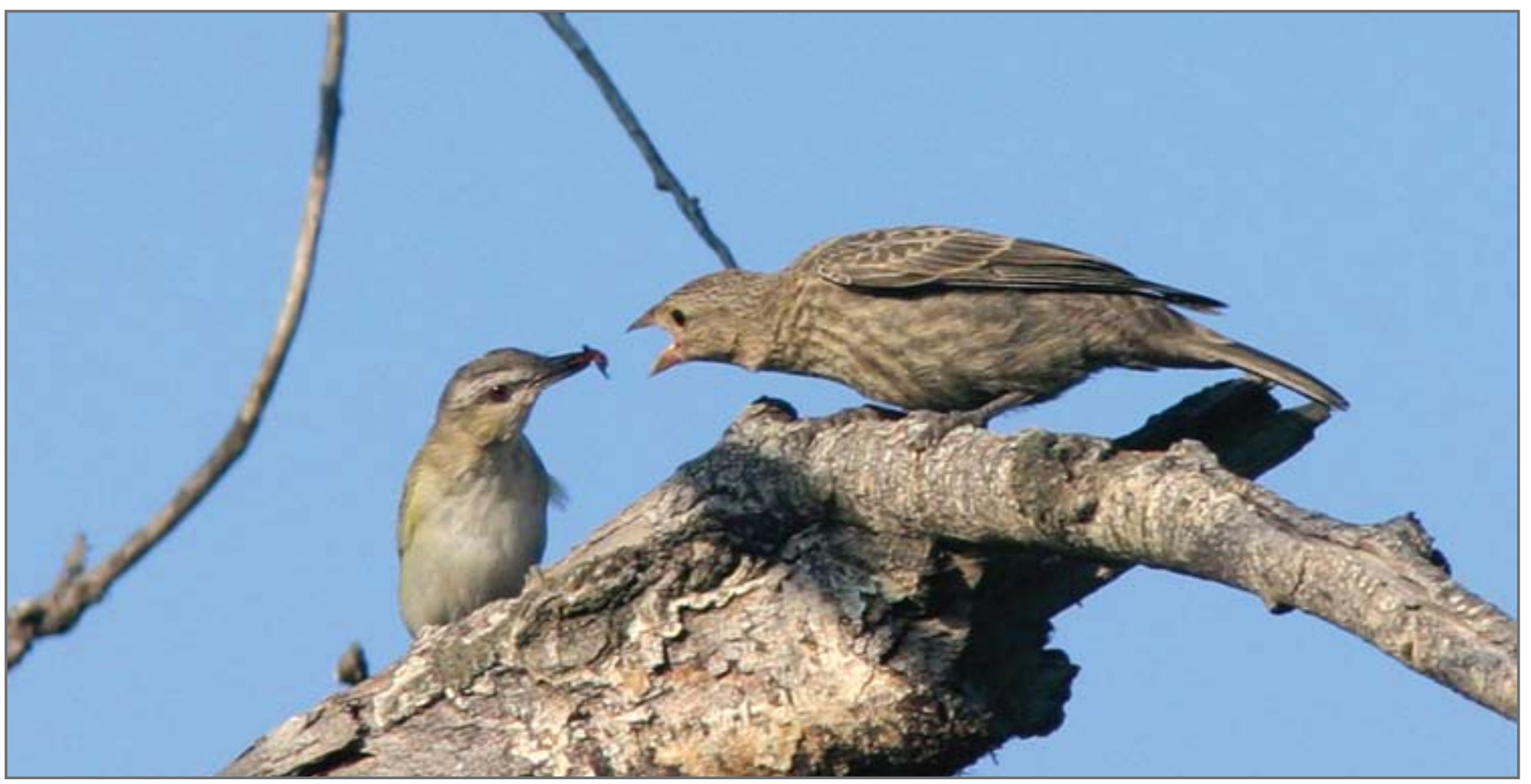

Red-eyed Vireo feeding a fledgling Brown-headed Cowbird. Photo credit: Christian Artuso

and a male Chestnut-sided Warbler (Setophaga pensylvanica). When first observed at 16:05 hr CDT on July 9, 1986, the cowbird was perched conspicuously on a dead branch approximately $1 \mathrm{~m}$ high at the edge of a mowed clearing in Turtle Mountain Provincial Park $\left(49^{\circ} 05 \mathrm{~N}\right.$, $\left.100^{\circ} 25 \mathrm{~W}\right)$, Manitoba. The Common Yellowthroat fed the cowbird nine times and the Chestnut-sided Warbler fed it five times. Neither adult female nor fledglings of either warbler species were observed. The cowbird's original host was not determined but both Chestnut-sided Warblers and Common Yellowthroats nest in Turtle Mountain Provincial Park ${ }^{14,15}$, and both species have been parasitized in various parts of their ranges. ${ }^{16,17}$

Song Sparrow (Super-active stage; cowbird 12-23 days out of nest) On July 21, 1989 at Delta Marsh $\left(50^{\circ} 11 \mathrm{~N}, 98^{\circ} 19 \mathrm{~W}\right)$, I observed one adult song sparrow feeding a cowbird fledgling. The cowbird flew from perch to perch amid Common Nettle (Urtica dioica var. procera) in Sandbar Willow (Salix interior), begging loudly between feeding bouts when it was fed bill loads of midges (Chironomidae) by the Song Sparrow, which remained in sight throughout the observation period. In succession, the cowbird followed the sparrow as it gleaned more insects from the nettles then perched momentarily on a downed willow stem where it was fed again Beginning at 10:21 hr, I observed the cowbird being fed 11 times over 45 minutes before it became obscured by vegetation and was silent, and the Song Sparrow flew from my sight. During this time, I scanned in vain for another adult Song Sparrow that may have been feeding another cowbird, because most parasitized Song Sparrow nests at Delta Marsh received more than one cowbird egg. ${ }^{18,19}$

\section{Common Yellowthroat (Super-} active stage; cowbird $12-23$ days out of nest) - On August 20, 1992, at 11:45 hr, my attention was drawn to the vociferous begging of a fledgling cowbird that was being fed by a male Common Yellowthroat. It was fed three times during the next 30 minutes, but neither an adult female yellowthroat nor other fledglings - yellowthroat or cowbird - were observed. The cowbird perched on a fallen stem of a sandbar willow near a clump of nettles, then disappeared. Feeding the single cowbird at this late date is what is interesting, not that the Common Yellowthroat apparently was rearing the cowbird, because across its range the yellowthroat is a frequent host of the Brown-headed Cowbird ${ }^{17,20}$ including at Delta Marsh. ${ }^{21}$

Two other exceptionally late dates of cowbird parasitism at Delta Marsh, to which the late record for the Common Yellowthroat can be compared, were of cowbird eggs laid during host egg laying in nests of two rarely used host species: Least Flycatcher (Empidonax minimus) on July 12, 1980 and Cedar Waxwing (Bombycilla cedrorum) on July 13, 1996. ${ }^{21}$ If the yellowthroat's nest was parasitized on or about this date, the cowbird would have been approximately 27 days old when observed on August 20, following the timeline of events of the nesting 


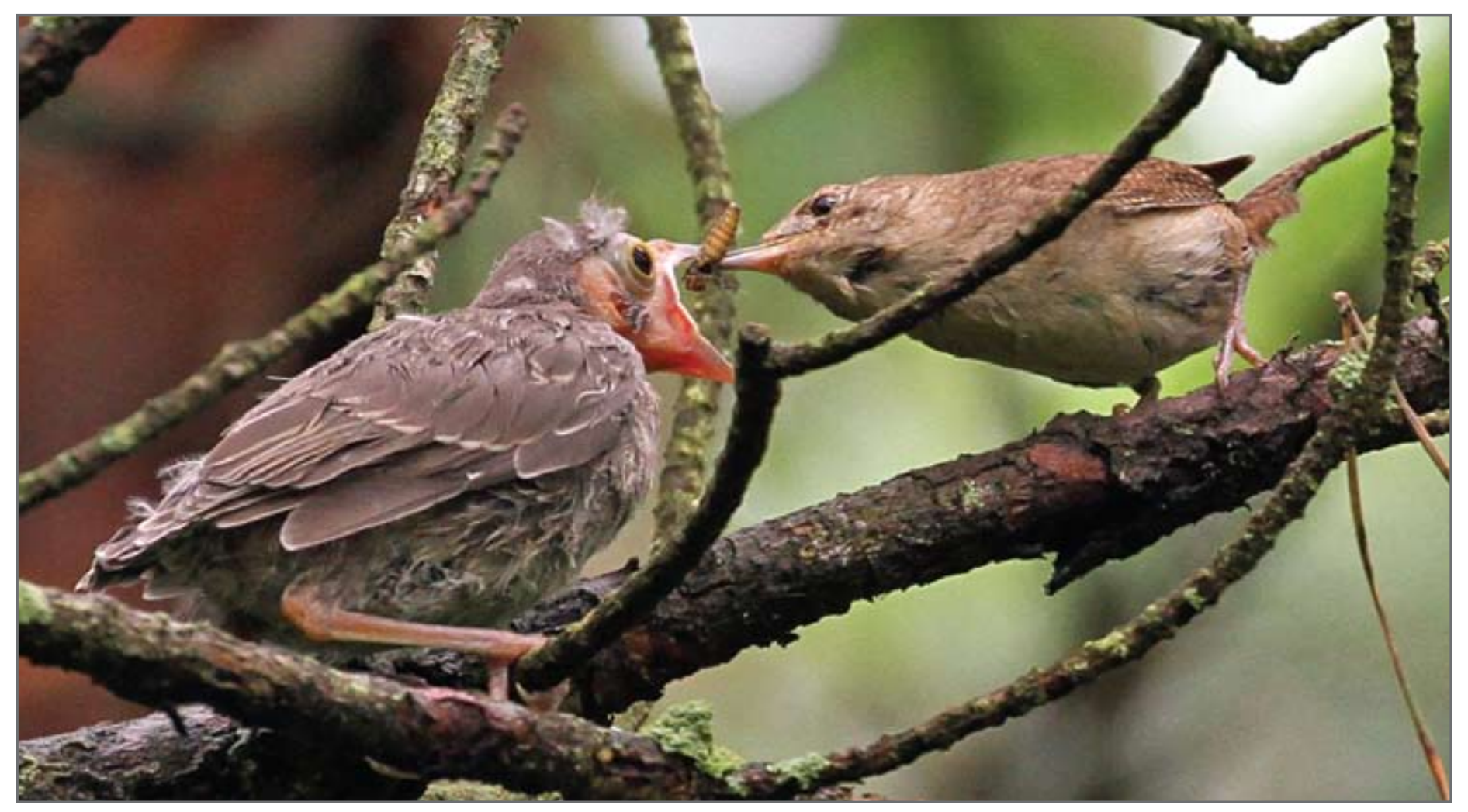

House Wren feeding a fledgling Brown-headed Cowbird. Photo credit: W.P. Brown

cycles of the two species. ${ }^{22,23}$

Orchard Oriole (Active stage; cowbird three to 13 days out of nest) - At 13:30 hr on June 29, 1993, I was alerted to the presence of a cowbird fledgling in a patch of nettles to which an adult male Orchard Oriole had flown to feed a cowbird perched on a willow stem. Returning about 10 minutes later with a second load of midges, the oriole fed the cowbird, flew out of my sight, and did not return over the next 30 minutes. In the meantime, the fully feathered fledgling had become obscured by the nettles, and attempts to locate it were unsuccessful. The female Orchard Oriole was never observed, but observations of colour-marked individuals in this population suggest fledged broods are divided between the parents, with males and females feeding separate young. ${ }^{24}$ In this case, the female may have been feeding fledged orioles elsewhere, or even another cowbird, as Orchard Oriole nests occasionally receive more than one cowbird egg at Delta Marsh. $^{24}$

Vesper Sparrow (Active stage; cowbirds three to 13 days out of nest) - This observation involves apparently the same adult Vesper Sparrow (Pooecetes gramineus), which fed five prey loads over 35 minutes to two cowbird fledglings side by side on the ground. These observations were made about 7 $\mathrm{km}$ northeast of Val Marie $\left(49^{\circ} 03 \mathrm{~N}\right.$, $\left.107^{\circ} 13 \mathrm{~W}\right)$, Saskatchewan, at 17:35 hr on July 7,1996 . I could not determine whether both cowbirds received a share of the food brought each time, but both fledglings appeared of similar age. No other adults or young, cowbird or host, were observed.

\section{Discussion}

Observations presented here of hosts feeding only Brown-headed Cowbird fledglings add to the large body of anecdotal observations that suggests that the cost of cowbird parasitism extends beyond the nestling period (Table 1), because from most parasitized broods only cowbirds survived, possibly having outcompeted host nestlings in the nest or fledglings after they have left the nest. Of observations of 254 family groups summarized in Table 1, plus the five records presented here, 227 groups (89 per cent) were observed feeding only cowbird fledglings. Additional support for this trend comes from information for hosts of the Bronzed Cowbird (M. aeneus) in Central America and northwestern South America, in which none of the 28 groups recorded with fledged cowbirds contained host fledglings. ${ }^{7}$ These observations taken together certainly suggest that costs to the reproductive success of hosts continue into the fledging period, but they fall short of confirming it, and further speculation is not warranted.

The cost of brood parasitism has typically been measured by comparing the number of young 
that fledged from unparasitized and parasitized nests, the latter frequently with fewer host young, if any, fledging. ${ }^{25}$ This figure is likely to be an overestimate, however, if the calculation could be based on accurate determinations of survival of cowbird and host young during the entire fledgling period. Albeit challenging field work, broods of an array of hosts should be radiotracked from the time all fledglings have left the nests, preferably with all individuals aged from hatching, or at least from fledging, until death or survival to independence is quantified, and fates of each fledgling are identified. Results of a study of radio-tracked broods of Ovenbirds (Seuirus aurocapilla) in Minnesota illustrate this point, in that one Ovenbird fledgling tracked from a parasitized nest died after 26 days, the only fledgling that died among 20 nests with no sign of depredation and an empty stomach. ${ }^{9}$ This preliminary result supports the pattern of brood reduction suggested by the anecdotal observations summarized here, but more studies are needed involving recently developed tracking technology focused on cowbird hosts, large and small. ${ }^{26}$

Many co-workers contributed to the success of the research at Delta Marsh over the years, for which I am grateful. Justin L. Rasmussen engaged in numerous discussions on feeding of fledgling cowbirds and, with Stephen K. Davis, commented on a draft of the manuscript. This work was funded chiefly by the Natural Sciences and Engineering Research Council of Canada, augmented by substantial in-kind support provided by the Delta Marsh Field Station (University of Manitoba). I thank Christian Artuso and W.P. Brown for the use of their photographs.

\section{LITERATURE CITED}

1. Woodward PW, Woodward JC (1979) Survival of fledgling Brown-headed Cowbirds. Bird-Banding 50:66-68.

2. Middleton ALA, Prigoda E (2001) What does "fledging" mean? Ibis 143:296-298.

3. Smith JNM (1981) Cowbird parasitism, host fitness, and age of the host female in an island Song Sparrow population. Condor 83:152-161.

4. Payne RB, Payne LL (1998) Brood parasitism by cowbirds: risks and effects on reproductive success and survival in Indigo Buntings. Behavioral Ecology 9:64-73.

5. Airola DA (1986) Brown-headed Cowbird parasitism and habitat disturbance in the Sierra Nevada. Journal of Wildlife Management 50:571-575.

6. Robinson SK (1990) Population dynamics of breeding Neotropical migrants in a fragmented Illinois landscape. Hagan JM, Johnston DW (Eds.). Pages 408-418 in Ecology and Conservation of Neotropical Migrant Landbirds. Smithsonian Institution Press, Washington D.C.

7. Sealy SG, Sánchez J, Campos RG, Marin M (1997) Bronzed Cowbird hosts: new records, trends in host use, and cost of parasitism. Ornitologia Neotropical 8:175184.

8. Rasmussen JL, Sealy SG (2006) Hosts feeding only Brown-headed Cowbird fledglings: where are the host young? Journal of Field Ornithology 77:269-279.

9. Peterson SM, Streby HM, Anderson DE (2012) Effects of parasitism by Brownheaded Cowbirds may persist into postfledging. Wilson Journal of Ornithology 124:179-183.

10. Klein NK, Rosenberg KV (1986) Feeding of Brown-headed Cowbird (Molothrus ater) fledglings by more than one "host" species. Auk 103:213-214.

11. Sealy SG, Lorenzana JC (1997) Feeding of nestling and fledgling brood parasites by individuals other than the foster parents: a review. Canadian Journal of Zoology 75:1739-1752.

12. MacKenzie DI (1982) The dune-ridge forest, Delta Marsh, Manitoba: overstory vegetation and soil patterns. Canadian Field-Naturalist 96:61-68.

13. Woodward PW (1983) Behavioral ecology of fledgling Brown-headed Cowbirds and their hosts. Condor 58:151-163.

14. Edie S, Maynard J, Taylor P (2003) Chestnut-sided Warbler (Dendroica pensylvanica). Pages 321-322 in The Birds of Manitoba. Manitoba Naturalists Society, Winnipeg, Manitoba.

15. Taylor P (2003) Common Yellowthroat (Geothlypis trichas). Page 337 in The Birds of Manitoba. Manitoba Naturalists Society, Winnipeg, Manitoba.

16. Friedmann H, Kiff LF (1985) The parasitic cowbirds and their hosts. Proceedings of the Western Foundation of Vertebrate Zoology 2:226-302.

17. Friedmann H, Kiff LF, Rothstein SI (1977) A further contribution to knowledge of the host relations of the parasitic cowbirds. Smithsonian Contributions to Zoology, Number 235.

18. McLaren CM, Woolfenden BE, Gibbs HL, Sealy SG (2003) Genetic and temporal patterns of multiple parasitism by Brownheaded Cowbirds (Molothrus ater) on Song Sparrows (Melospiza melodia). Canadian Journal of Zoology 81:281-286.

19. Woolfenden BE, McLaren CM, Sealy SG, Gibbs HL (2004) Community-level patterns of parasitism: use of three common host species by a brood parasitic bird, the Brown-headed Cowbird. Écoscience 11:238-248.

20. Hofslund PB (1957) Cowbird parasitism of the Northern Yellow-throat. Auk 74:42-48.

21. Sealy SG (In preparation) Cowbird hosts at Delta Marsh.

22. Lowther PE (1993) Brown-headed Cowbird (Molothrus ater). In Birds of North America. Number 47. (Poole A, Gill F, Eds.). Philadelphia: The Academy of Natural Sciences; Washington, D.C.: The American Ornithologists' Union.

23. Guzy MJ, Ritchison G (1999) Common Yellowthroat (Geothlypis trichas). In Birds of North America. Number 47. (Poole A, Gill F, Eds.). Philadelphia: The Academy of Natural Sciences; Washington, D.C.: The American Ornithologists' Union.

24. Sealy SG (1980) Breeding biology of Orchard Orioles in a new population in Manitoba. Canadian Field-Naturalist 94:154-158.

25. Ortega CP (1998) Cowbirds and Other Brood Parasites. University of Arizona Press, Tucson.

26. Lorenzana JC, Sealy SG (1999) A metaanalysis of the impact of parasitism by the Brown-headed Cowbird on its hosts. Studies in Avian Biology 18:241-253. 